\title{
Sectoral Output Gaps - Estimates for Bulgaria
}

\section{Nikolay Peykov*}

\begin{abstract}
The paper reveals the impact of the output gap of the various sectors on the total output gap in the Bulgarian economy. The HP filter procedure has been applied in order to evaluate the potential output of each sector. The results show different cyclical dynamics between sectors which assumes that the structural change of production is driven not only by cyclical factors but rather by fundamental. As some of the sectoral output gaps appear to be much more volatile than others a shock in one sector can have an impact on the rest of the economy through the cross-sectoral dependencies. The last part of the paper reveals the contribution of the individual sector output gap to the overall economy output gap. Based on that, the sectors determining the cyclical state of the economy over the period 2000-2019 have been identified.
\end{abstract}

JEL: C50, E01, E32, 010

Keywords: potential output, output gaps, GVA, HP filter

\section{Introduction}

The most widely used indicator for assessing the level of economic development of a country is the Gross Domestic Product (GDP). As such, economists have always been interested in its upper bound level known in the literature as potential output (resp. potential GDP). One of the starting points in the discussion of potential output was given by Okun (1962). According to his views, the definition of potential GDP should answer the general question of "How much output can the economy produce under conditions of full employment?" (Okun, 1962). The question indirectly implies that the potential should be determined by the maximum utilisation of the factors of production. In fact, such a definition makes little economic sense. On the one hand, it ignores some types of unemployment, such as frictional and voluntary. On the other hand, the full use of factors of production makes them very limited, which causes an increase in their price and a boom in inflation. Therefore, economists dwell on a slightly more restrictive definition according to which the potential GDP is the maximum output an economy can sustain without generating a rise in inflation (De Masi, 1997). In general, the potential output can be considered as an equilibrium position of the economy that corresponds to the so-called in theory "steady state".

Depending on the theoretical paradigm, the interpretation and characteristics of the steady state may differ. The two main schools in economics provide different views on the output gap and its characteristics. The classical view sees the output gap as

\footnotetext{
Republic of Bulgaria Ministry of Finance
} 


\section{Articles}

a temporal deviation from the long-term equilibrium level and caused mostly by exogenous productivity shocks to aggregate supplies that determine both the longterm and short-term fluctuations in output (Scacciavillani, F., \& Swagel, P., 1999). In this framework, the deviation from the potential is only temporary and can be easily remedied by appropriate and timely economic policy measures. For its part, Keynesian economics views the output gap as a longer divergence caused by a mismatch between supply and demand. And more precisely it is due to the lack of flexibility in the adjustment of the prices and wages, which limits the possibility of adjusting it with the tools of economic policy.

Despite the development of economic theory and practice in determining the potential product, its main drawback is the concentration of research almost exclusively on total GDP. At the sectoral level, such analyses are practically absent, which is mainly due to the technical limitations in the data on capital accumulation and the depreciation rate in each sector. However, this in no way justifies the insufficient theoretical study in this area, which can at least begin with a study of the different rate of sectoral substitution of factors of production. In any case, every theoretical paradigm needs to be refreshed and a new point of view introduced. This paper will try to start a discussion about the sectoral output gaps and their impact on the general state of the economy, based on estimates for Bulgaria. So, the aim of the report is to establish how sectoral deviations from a potential product affect the overall deviation from the potential Gross value added/GDP in Bulgaria. Therefore, several tasks are set: 1) To choose an appropriate method for assessing the individual potential product for

\section{Sectoral Output Gaps - Estimates for Bulgaria}

each sector and its deviation from the potential level; 2) To determine the characteristics and features of the output gap by sectors; 3) To establish the interdependencies between the industries. The object of the study is the deviation from the potential at the sectoral level in the Bulgarian economy.

\section{Methodology for assessing the potential output}

Since the potential output is an unobservable concept there are several widely accepted methods used to be estimated. Although all of them use more or less filtering methods, they can be broadly divided into structural and non-structural or statistical filtering approaches. The latter is a purely statistical methodology and can be based on single-variate (SV) or multivariate filter (MV). The simplest methodology used is the singlevariate filter as it actually extracts the trend of the actual GDP series while the difference is the estimate of the potential output. For that type of calculations the Hodrick-Prescott filter is the most commonly used (Hodrick, R.J., and E.C. Prescott, 1997). At the same time, there are also disadvantages to this approach, as it does not take into account information from other economic data such as inflation, labor market indicators and investment. The filtering methods attempt to extract those parts of the movement in the time series that are due to the cycle, leaving the rest as a potential output. In this way, two components are separated, one permanent and one exhibiting a cyclic behavior. The difficulty comes from determining a constant or cyclical level that can shift as a result of a change in productivity. The HP filter minimizes the weighted average of the deviations in the trend. Formally, it applies the following minimization function:

$$
\operatorname{Min}\left(\sum_{t=1}^{T}\left(y_{t}-y_{t}^{T}\right)^{2}+\lambda \sum_{t=2}^{T-1}\left(\Delta y_{t+1}^{T}-\Delta y_{t}^{T}\right)^{2}\right)
$$




\section{Articles}

Where $y_{t}$ and $y_{t}^{\top}$ are logarithms of the actual and trend output respectively, $t$ accounts for the number of observations, $\lambda$ is the weighting coefficient that controls the smoothness of the time trend. If the values of the weighting coefficient are low, the trend will follow the actual series more closely, whereas a higher value of $\lambda$ implies smoother estimates for the trend output that converges with the mean growth rate for the whole period. Accordingly, a higher value of the parameter also means a lower value of the output gap and vice versa. The first part of the equation minimizes the difference between the actual and potential output while the second determines the variance in the trend series. Here comes the tricky part of using the HP filter as a procedure for obtaining the potential output. The choice of the value for the smoothing parameter $\lambda$ is arbitrary thus affecting the size of the output gap. From a statistical perspective "any nonstationary series (integrated of order 1) can be decomposed into an infinite number of non-stationary trend and stationary cycle combination" (Giorno, C., et al., 1995, p. 8) making this way the possible choice for the parameter practically infinite. Although no statistical method has been developed to determine the value of the parameter, the values used in Hodrick and Prescott's original paper (Hodrick, R.J., and E.C. Prescott, 1997) are often applied in the economic literature. However, it should be borne in mind that their choice for annual, quarterly and monthly data is based on the ratio between cycle variation and trend variation. Another disadvantage of this type of methods is the so-called end-ofsample problem. It means that towards the edges of the sample the filter gradually turns into an asymmetric one pulling the first few and the last few observations closer to the actual data. Some analyses (e.g. St-Amant, P., \& S. van Norden, 1997) show that the weights of the central observations account for 6 percent, while the weight of the last observation is 20 percent. Therefore, the assessment of the potential product for the whole period may change when new observations are added or data are revised. A possible weakness of the filtering approach could occur if the time series have a structural break. In this case, the effect of the break could be spread over the next several observations.

The structural approach is much more theory consistent taking into account information about the factors of production and other endogenous influences. Such type of methods derives the unobservable potential output variables by modelling the supply-side of the economy which allows for long-term divergence from equilibrium. This improves the interrelationship between macroeconomic variables and the results of their interaction, which in turn offers more opportunities for a reliable assessment of economic policy and the implementation of adequate measures. The application of this method requires the construction of an appropriate model, which, however, requires a serious set of data. This requirement can be a problem with a limited set of data or if their quality is questionable. At the same time, statistical smoothing procedures are used for some of the variables, which raises already known questions from the univariate filters (Cerra, V., and S.C. Saxena, 2000). In this case, the most commonly used approach is the socalled production function, which evaluates the effectiveness of combining production factors to achieve the potential output. Its general idea is to disaggregate the factors of production as much as possible. The three known components are basic: labor, capital and total factor productivity, each of them can be further broken down into its component parts, reflecting demographic changes, capital utilization, number of hours worked, etc. Although there is no consensus on the best 


\section{Articles}

functional form, the most commonly used are the constant elasticity of substitution (CES) and its particular form the Cobb-Douglas (CD) production function. The latter is more often used because of its simplicity, while its longterm results are often close to the expected economic development.

As the CD function have two production factors it takes the following form:

$Y_{t}=A_{t} L_{t}^{\alpha} K_{t}^{1-\alpha}, 0<\alpha<1$

Where stands for the total factor productivity (TFP), represents the capital

$$
Y_{t}=\left[\delta\left(B_{t} L_{t}\right)^{\frac{\sigma-1}{\sigma}}+(1-\delta)\left(X_{t} K_{t}\right)^{\frac{\sigma-1}{\sigma}}\right]^{\frac{\sigma}{\sigma-1}}, 0<\delta<1, \sigma>0
$$

Where $B_{t}$ and $X_{t}$ are indexes of labor and capital augmenting technical progress respectively, captures the functional distribution of income while $\sigma$ stands for the elasticity of substitution again. This framework is much more flexible compared to the CD function as factor income shares are linked with the productivity and real costs. At the same time it is not necessary for the substitution parameter to be equal to one and can be directly estimated from the data.

However, the functional form of the CES function is practically useful for the purpose of calculating the sectoral potential output and output gaps. The main problem lies in the determination of capital stock by sectors. A possible approach is to use the available statistics on tangible fixed assets (TFA), assuming that the ratio of capital reserves coincides with the ratio of fixed assets by sector. However, it should be borne in mind that the application of such an approach is associated with some inaccuracies, the main of which are (Ganev, K., 2005):

The sectoral dynamics of capital is determined not only by the accumulation of tangible fixed assets, but also by the initial value of the capital stock and the rate of stock, is total employment, $t$ is the time, while the a term accounts for the constant elasticity of output with respect to labor. The elasticity coefficient is calibrated in a way to match the long-term average income share of labor thus, it is necessary that this share be stable and nearly constant over time. Given that the substitution of factors is a unit, the relative increase in the price of one factor will be accompanied by a relative decrease in its utilization.

An alternative approach is the CES function which can be expressed as follows: capital depletion for the respective industry. It is logical that these two values are different for individual industries and for the economy as a whole.

Some of the acquired fixed assets are not necessarily new, as a result of which their recording in the value of the capital for the respective period is not quite accurate. The reason is that the acquisition price does not correctly reflect the degree of capital depletion.

The approach assumes that the dynamics of intangible assets coincides with those of tangible fixed assets. Also, their uneven distribution between sectors is not taken into account. In today's global economy, the importance of intangible fixed assets is growing and such a restriction would be unrealistic.

Another issue is the potential employment rate in individual sectors. Is it appropriate to consider the number of unemployed as the potential stock of new employees that can be employed in a given sector? Given that the development of a sector and the increase in employment in it may mean an increase in wages at a higher than average rate. This, in turn, would force some people employed 


\section{Articles}

in the other sectors to move to the faster developing one. In such a case, accepting the unemployed as the only source of labor would be a limiting condition. These reasons make the CES function unsuitable for calculating the potential sectoral output. Accordingly, despite its shortcomings, a Hodrick-Prescott univariate filter will be applied for the assessment of the sectoral potential outputs.

\section{Estimates of the potential output by sectors}

In order to get the sectoral output gaps, quarterly data for Gross value added in Bulgaria were used. The $A^{*} 10$ industry breakdown was used with quarterly frequency, constant prices of 2015 in euro not seasonally adjusted. For the seasonal adjustment the Census X-12 procedure was applied with an additive method (Arabic, V., 2014). As was already mentioned the HP filtering approach will be applied in order to extract the cycle from the series and obtain the potential output. Based
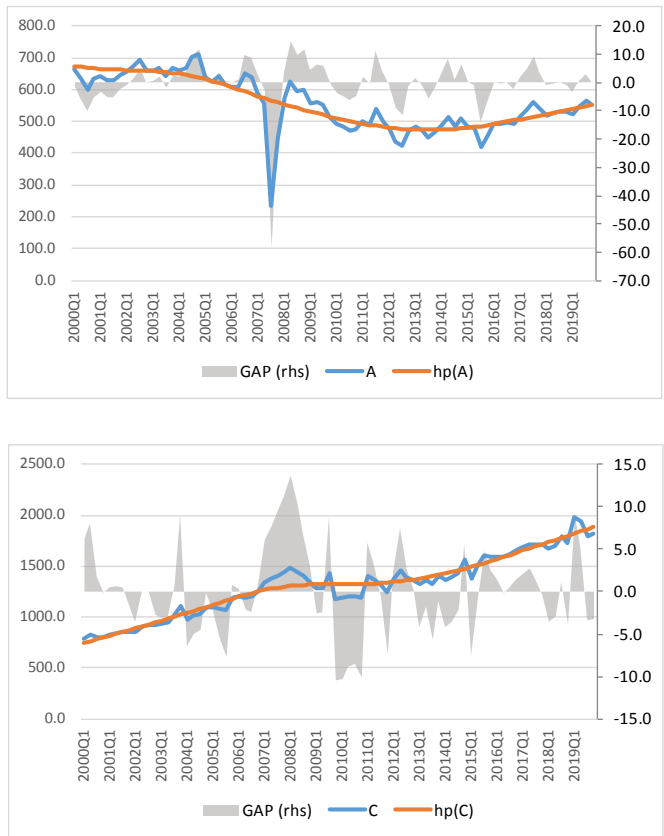

on the calculated potential product for each sector a relative output gap is determined according to the following formula:

$y_{i, t}=\left(Y_{i, t}-\bar{Y}_{i, t}\right) / \bar{Y}_{i, t} * 100$

Where the small letter of $y$ is the relative output gap, the capital letter $Y$ is for the actual GVA series, the stands for the potential output estimated with HP filter, $i$ accounts for the particular sector in the $A^{*} 10$ industry breakdown and $t$ is the time. The results are present in the following Figure 1, for the potential output check Appendix, Table 3, while for the output gaps see Appendix, Table 4. The obtained results for the output gap of the total GVA are similar to those obtained by Todorov, I., \& Aleksandrov, A., (2018), who apply a production function to determine the potential GDP in Bulgaria. This supports the results as reliable both on a sectoral and overall level.
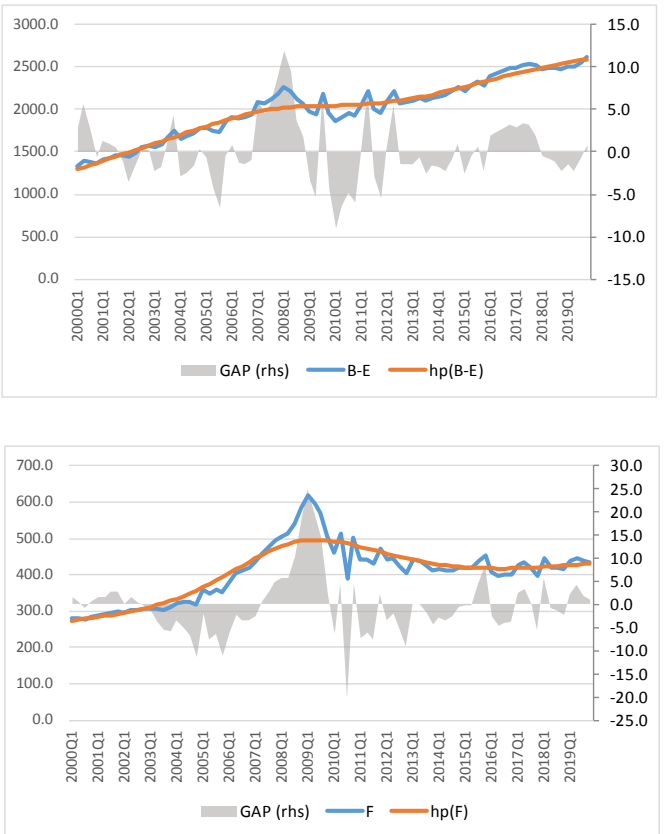

Figure 1. Sectoral* potential output and output gaps, 2000q1-2019q4 in mln euro and \% 


\section{Articles}

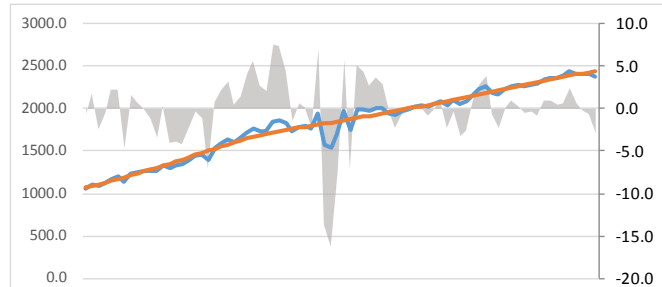

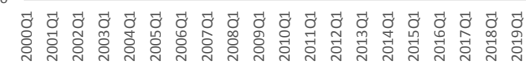
GAP (rhs) G-I $\longrightarrow \mathrm{hp}(\mathrm{G}-\mathrm{I})$

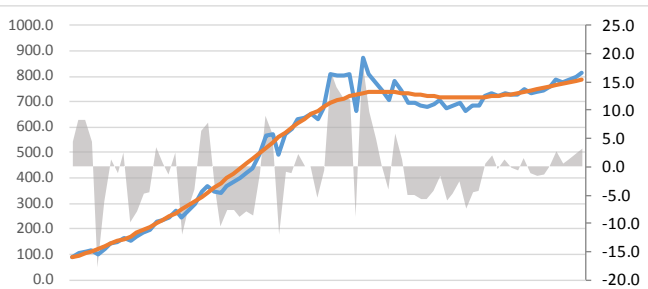

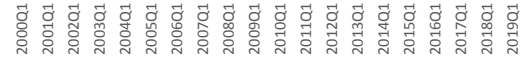

$$
\mathrm{GAP}(\mathrm{rhs}) \longrightarrow \mathrm{K} \longrightarrow \mathrm{hp}(\mathrm{K})
$$
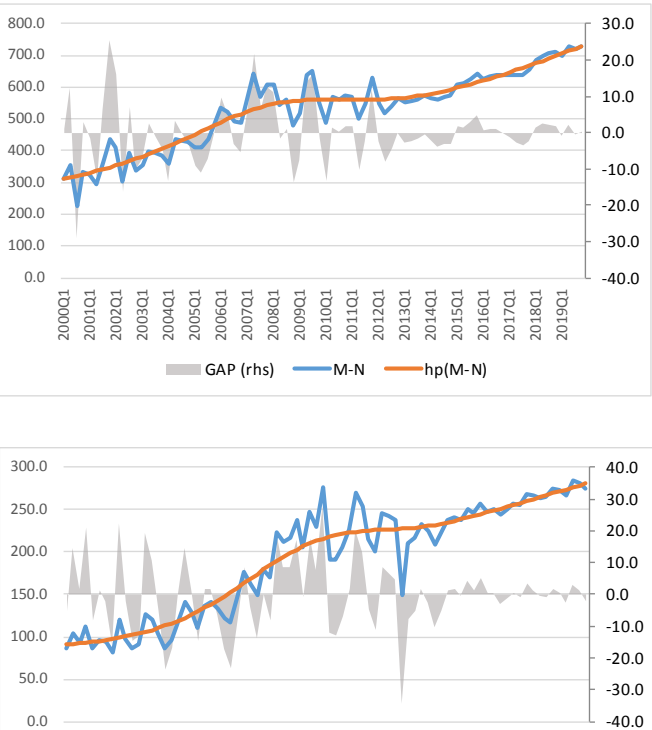

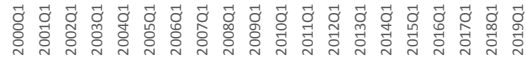

$$
\text { GAP (rhs) } \longrightarrow \mathrm{R}-\mathrm{U} \longrightarrow \mathrm{hp}(\mathrm{R}-\mathrm{U})
$$

Sectoral Output Gaps - Estimates for Bulgaria

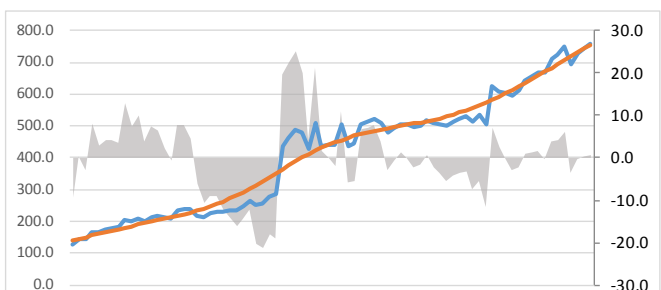

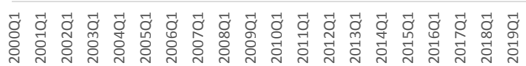

$$
\text { GAP (rhs) } \longrightarrow \mathrm{J}
$$

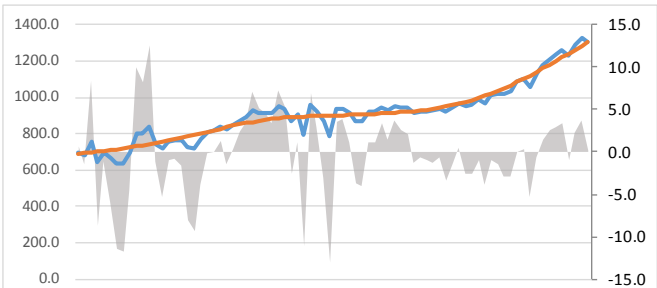

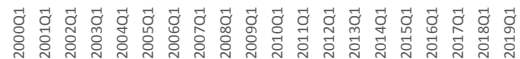

$$
\text { GAP (rhs) } \longrightarrow \mathrm{L} \longrightarrow \mathrm{hp}(\mathrm{L})
$$
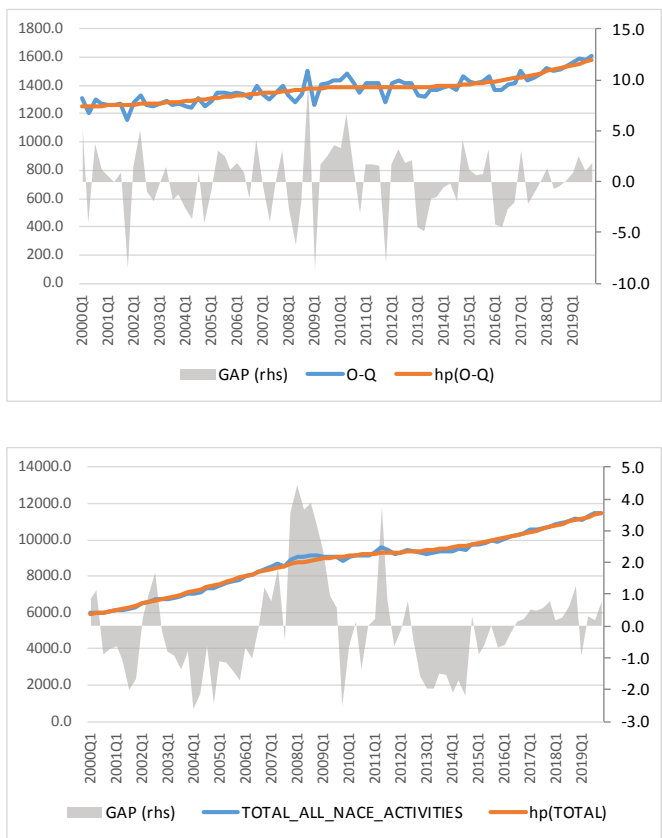

Figure 1. Sectoral* potential output and output gaps, 2000q1-2019q4 in m/n euro and \% Source: Own calculations based on Eurostat, National Accounts (ESA 2010) data 


\section{Articles}

*The represented sectors are as follows:

A Agriculture, forestry and fishing

B-E Industry (except construction)

C Manufacturing

$F \quad$ Construction

G-I Wholesale and retail trade, transport, accommodation and food service activities

$\mathrm{J}$ Information and communication

$\mathrm{K} \quad$ Financial and insurance activities

L Real estate activities

M_N Professional, scientific and technical activities; administrative and support service activities

$\mathrm{O}-\mathrm{Q}$ Public administration, defence, education, human health and social work activities

R-U Arts, entertainment and recreation; other service activities; activities of household and extra-territorial organizations and bodies

Total_ALL_NACE_Activites Total Gross Value Added in the economy

The visual analysis gives a lot of information about what is happening in the economy in the period 2000-2019. First, the sectoral potential output, estimated through HP filtering, has a very different trend. The potential output of Agriculture sector is mostly decreasing after the global economic and financial crisis of 2008-2009. At the same time sectors like Construction, Financial and insurance activities and partially Public administration show lack or modest potential development, especially after the crisis. The Real estate activities; Professional, scientific and technical activities; Arts, entertainment and recreation reported a boost just a few years after the plateau around the crisis. At the other end are the sectors like Wholesale and retail trade, transport, accommodation and food service activities; Information and communication and in some sense Manufacturing that do not seem to have experienced a significant delay throughout the period. While the potential output of some sectors is running out, in others it has not only increased, but is doing so at a faster pace. These observations suggest that the structural change of GVA is due not only to short-term cyclical fluctuations, but to lasting fundamental causes. Some analysis shows that the cyclicality of a particular industry depends mainly on three indicators: tradability, factor intensity and external finance dependence. They come to the conclusion that "industries that are (i) less tradable, (ii) more labor-intensive, and (iii) more reliant on external finance tend to be more sensitive to the credit cycle, both in terms of value added and employment growth" (Giovanni Dell'Ariccia at al., 2020, p. 14). However, these observations explain only the cyclical component, although in some cases a longer one, but not the reasons for the long-term qualitative changes in the structure of total production.

The second most obvious thing is the different volatility of the output gaps for the different sectors. As some look much more persistent, others are much more frequent and somehow sharp. Some basic characteristics of the sectoral gaps are present in Table 1.

Table 1. Basic characteristics of sectoral output gaps

\begin{tabular}{|lll|lll|ll|}
\hline Sector & MAX & Time & Sector & MIN & Time & Sector & Variance \\
\hline R-U & 27.7 & $2009 Q 4$ & A & -58.6 & $2007 Q 3$ & R-U & 120.0 \\
\hline M_N & 25.4 & $2001 Q 4$ & R-U & -34.2 & $2012 Q 4$ & J & 85.5 \\
\hline J & 25.1 & $2008 Q 3$ & M_N & -28.9 & $2000 Q 3$ & A & 76.5 \\
\hline F & 25.0 & $2009 Q 1$ & J & -21.2 & $2007 Q 2$ & M_N & 67.5 \\
\hline K & 18.8 & 201102 & F & -20.2 & $2010 Q 3$ & K & 43.9 \\
\hline A & 14.6 & $2008 Q 2$ & K & -17.9 & $2001 Q 1$ & F & 43.6 \\
\hline C & 13.7 & $2008 Q 1$ & G-I & -16.2 & $2009 Q 3$ & C & 27.6 \\
\hline
\end{tabular}




\begin{tabular}{|lll|lll|ll|}
\hline Sector & MAX & Time & Sector & MIN & Time & Sector & Variance \\
\hline L & 12.5 & $2002 Q 4$ & L & -13.1 & $2009 Q 4$ & L & 22.7 \\
\hline B-E & 11.9 & $2008 Q 1$ & C & -10.5 & $2009 Q 4$ & G-I & 14.7 \\
\hline O-Q & 9.7 & $2008 Q 4$ & B-E & -9.0 & 201001 & B-E & 13.9 \\
\hline G-I & 7.5 & $2007 Q 2$ & O-Q & -8.6 & $2009 Q 1$ & $0-Q$ & 10.4 \\
\hline GVA & 4.2 & $2008 Q 1$ & GVA & -2.6 & $2009 Q 4$ & GVA & 2.1 \\
\hline
\end{tabular}

Source: Own calculations.

*The represented sectors are as follows:

A Agriculture, forestry and fishing

B-E Industry (except construction)

C Manufacturing

$F \quad$ Construction

G-I Wholesale and retail trade, transport, accommodation and food service activities

$\mathrm{J}$ Information and communication

$\mathrm{K} \quad$ Financial and insurance activities

L Real estate activities

M_N Professional, scientific and technical activities; administrative and support service activities

O-Q Public administration, defence, education, human health and social work activities

$\mathrm{R}-\mathrm{U}$ Arts, entertainment and recreation; other service activities; activities of household and extra-territorial organizations and bodies

GVA Total Gross Value Added in the economy

The first three columns of Table 1 represent the sector of the economy, the maximum output gap that was observed in the period 2000Q1-2019Q4 and the moment itself. The next three columns are similar with the only difference that they are structured according to the minimum output gap per sector or the maximum of all negative gaps. The last part arranges the sectors according to their variance. Stating the obvious, the Arts, entertainment and recreation sector is the most unstable sector with huge ups and downs. The positive gap in the sector is highest in the period when the crisis should be felt most, and the negative one a few years later. These observations lose economic logic, given the labor-intensive nature of the industry and its strong dependence on domestic demand. Applying data for the TFA related expenditures in Bulgaria Pirimova, V. and Sotirova, M. (2018, p. 12), identify the Real estate sector, Construction and Finance and insurance services as the most volatile. Those industries are in the middle of the table according to the size of the output gap variance which indicate their high dependence of the TFA. On the other hand, the potential output of the Information and communication services sector is much greater than its actual value added just before the crisis, after which things turned upside-down. In this case, the development seems much more intuitive if we accept the serious shortage of qualified personnel. This shortfall was subsequently offset by lower activity in the economy as a whole, fewer orders to the sector and high capital adequacy. At the same time, the sharp shift in the data on the actual GVA between the last quarter of 2007 and the first of 2008 indicate a possible structural break, which may be due to some changes in the methodology. Agriculture, although not experiencing high levels of overheating, saw a huge decline as early as mid-2007. The most stable and less volatile are the Public administration; Industry (except construction) and Wholesale and retail trade, transport, ect. Having in mind that the variance of Manufacturing is much higher than the one of Industry (except construction), probably the latter gain some stability from Mining and querying; Electricity, water supply and gas subsectors as those are largely stateregulated. Finally, all these imbalances at the sectoral level seem to be offset by each other, 


\section{Articles}

so that the deviation from the potential of the total GVA remains quite stable over time.

\section{Key sectors determining the total GVA output gap}

This part of the analysis will be designed to identify the sectors moving the overall output gap for the economy in one direction or another. First of all, it should be borne in mind that the individual economic sectors are not independent of each other. There is a strong interconnectedness between them, the product of one sector is often used as a resource of another. In such cases, productivity growth could have increased the need for output growth in other sectors. Conversely, it is possible that the increased production in one industry will take away the factors of production from the others, and there will be a decline in the potential of the latter. Similar trends are recently observed in labor-intensive sectors such as Agriculture and the Textile industry, where there is an outflow of labor due to low productivity and wages. This limits their potential and their share in the overall structure of GVA.

To get some idea of the cyclical relationship between the sectors, simple correlation coefficients of the sectoral output gaps are calculated, based on the quarterly data. The data are presented in Table 2.

Table 2. Sectoral output gap correlations

\begin{tabular}{|c|c|c|c|c|c|c|c|c|c|c|}
\hline Sector / Correlation & A & B-E & C & $\mathbf{F}$ & G-I & $\mathbf{J}$ & K & M_N & $0-Q$ & $\mathbf{R}-\mathbf{U}$ \\
\hline A_AGRICULTURE & 1.00 & & & & & & & & & \\
\hline B_E_INDUSTRY & -0.13 & 1.00 & & & & & & & & \\
\hline C_MANUF & -0.18 & 0.85 & 1.00 & & & & & & & \\
\hline F_CONSTR & 0.02 & 0.14 & 0.23 & 1.00 & & & & & & \\
\hline G_I_WHOLESALE & -0.30 & -0.02 & 0.00 & -0.24 & 1.00 & & & & & \\
\hline J_INFORMATION & 0.38 & 0.01 & -0.02 & 0.34 & -0.39 & 1.00 & & & & \\
\hline K_FINANCIAL & -0.28 & -0.15 & -0.17 & -0.05 & 0.10 & 0.05 & 1.00 & & & \\
\hline L_R_ESTATE & -0.14 & 0.10 & 0.16 & 0.02 & 0.22 & -0.18 & 0.04 & & & \\
\hline M_N_PROFESS & -0.11 & 0.16 & 0.22 & 0.19 & -0.06 & -0.06 & -0.12 & 1.00 & & \\
\hline O_Q_PUBLIC & -0.09 & -0.11 & 0.02 & -0.01 & -0.17 & -0.08 & 0.14 & -0.29 & 1.00 & \\
\hline R_U_ARTS & 0.08 & 0.12 & 0.12 & 0.27 & -0.20 & 0.40 & 0.00 & 0.00 & 0.19 & 1.00 \\
\hline
\end{tabular}

Source: Own calculations.

*The represented sectors are as follows:

A Agriculture, forestry and fishing

B-E Industry (except construction)

C Manufacturing

F Construction

G-I Wholesale and retail trade, transport, accommodation and food service activities

$\mathrm{J}$ Information and communication

$\mathrm{K} \quad$ Financial and insurance activities

$\mathrm{L} \quad$ Real estate activities

M_N Professional, scientific and technical activities; administrative and support service activities

O-Q Public administration, defence, education, human health and social work activities
R-U Arts, entertainment and recreation; other service activities; activities of household and extraterritorial organizations and bodies

What Table 2 shows us is that there is no particularly strong cyclical relationship between most sectors, at least when quarterly data are used. The reason may lie in the delayed response of some sectors to shock in others. For example, the shock in Agriculture in mid-2007 may affect other sectors over the next one or two quarters. In particular, the 


\section{Articles}

output gap of the primary sector is negatively related to that of Trade, Finance, Industry, Real estate and Professional services. This means that when the sector operates below its potential, those other five should exceed their own potential. The opposite is true for the relationship between the primary and IT sector. The latter, however, is positively correlated with Construction while negatively with Trade but mostly in line with Arts, entertainment and recreation. Those relations are strongly dependent on the characteristics of the particular sector, which can act as a consumer of production from the other sectors, a supplier to the others, both consumer or supplier or neither. Applying a methodology based on the use of input-output tables of Bulgaria Minassian, G. (2017) shows that some sectors exhibit strong relation with others both as consumer and producer of output. Those in particular are mostly part of the Manufacturing sector, but also Construction; Land transport and Advertising and market research services. On the other hand, mostly service related activities are with weak consumer and producer relations. An example of a mixture is the Real estate sector that is a weak consumer of the output of the other industries while it is a strong producer of output for them. These links show that interdependencies between sectors vary a lot, depending on the characteristics of the output, whether it is for final use or intermediate use. In the wake of limited resources, the rapid development of some industries may act as either a brake or a trigger on others, changing the whole structure of the economy in this way. In fact, these dependencies are of great importance for the overall labor productivity and development of the Bulgarian economy. The question arises as to what extent the imbalance in some markets can be offset by the imbalance of others. It seems that such "compensation" is at least partly possible,
Sectoral Output Gaps - Estimates for Bulgaria

given the significantly lower variation of the total production in the economy. The answer to this question requires the application of much more complex and accurate econometric techniques, so it will be considered in a separate study.

At the same time, the sectors of the economy are different in size and occupy a different share in the total GVA. Deviation from the potential level of a particular sector does not mean that it will be transferred to total production in a similar amount. In order to be more precise in determining the impact of each sector on the output gap of the total GVA, individual contributions should be determined. Considering that the output gap of the total GVA can be expressed as a sum of the separate sectoral gaps it takes the following form:

$\sum y_{i, t}=\sum\left(Y_{i, t}-\bar{Y}_{i, t}\right) / \bar{Y}_{G V A, t} * 100$

Where the small letter of $y$ is the relative output gap contribution of each sector, the capital letter $Y$ is for the actual GVA series, the stands for the potential output estimated with the HP filter, while is the potential output of the total GVA, $i$ accounts for the particular sector in the $A^{*} 10$ industry breakdown and $t$ is the time. A detailed breakdown of contributions by sectors and quarters is presented in the Appendix, Table 5. For an illustrative purpose, Figure 2 is presented, where the contributions by quarters are summed in annual data, due to the same reason the sectors Wholesale and retail trade, transport, accommodation and food service activities; Real estate activities; Professional, scientific and technical activities; Public administration; Arts, entertainment and recreation, are also united. 


\section{Articles}

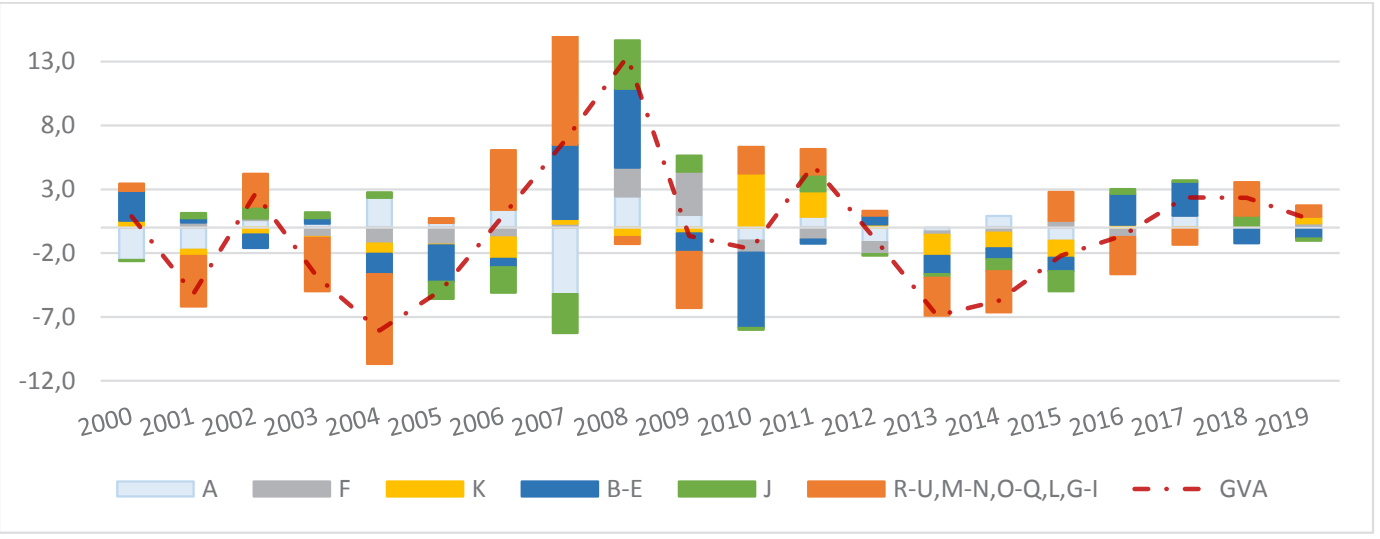

Figure 2. Annual Sectoral Gaps contribution to total GVA output gap, in \% Source: Own calculations

*The represented sectors are as follows:

A Agriculture, forestry and fishing

B-E Industry (except construction)

C Manufacturing

F Construction

G-I Wholesale and retail trade, transport, accommodation and food service activities

$\mathrm{J}$ Information and communication

$\mathrm{K} \quad$ Financial and insurance activities

L Real estate activities

M_N Professional, scientific and technical activities; administrative and support service activities

$\mathrm{O}-\mathrm{Q}$ Public administration, defence, education, human health and social work activities

$\mathrm{R}-\mathrm{U}$ Arts, entertainment and recreation; other service activities; activities of household and extraterritorial organizations and bodies

GVA Total Gross Value Added in the economy

The estimated data shows that the main contributors for the overheating in 2007 are Manufacturing; Wholesale and retail trade; Professional services and Real estate activities, while the Financial and Construction sectors have a minor contribution. That is somehow in contrast with the expectations, having in mind the sharp rise in house prices, the strong growth of construction and households credit growth during that time. In the next 2008 the Manufacturing sector continues to overheat substantially, while Wholesale and retail trade; Professional services and Real estate activities already contribute negatively mainly because of the last quarter of the year. On the contrary, the IT sector, Arts and entertainment; Agriculture and Construction turned sharply from negative output gaps, or slightly positive in the case of Construction sector, to a strong overheating. This is striking, although in many developed countries the economic crisis has already begun, some sectors in Bulgaria are still exceeding their capacity. The overall output gap also remains positive, but already relies on different foundations. At the end of 2009, the overall output gap was already negative as a key contributor to the decline in Wholesale and retail trade; Manufacturing and Real estate activities. At the same time the response of the Construction; Information and communication services; Arts, entertainment and recreation; and Agriculture sectors is much slower. The recovery of the Industry (except construction) sector takes a long time and it reached its potential levels only temporarily by the beginning of 2011. What brings the Bulgarian economy out of the crisis are the sectors of Financial and insurance activities; Wholesale and retail trade and to a lesser extent Public administration. The results of Minassian, G. (2017) show that Land transport; transport via pipeline services, Real estate services 


\section{Articles}

and some of the Manufacturing industries are part of the key sectors for the economy in the first post-crisis years. Based on data over the period 2007-2017, Kolev, K., (2020) also proves that Agriculture; Wholesale and retail trade, transport, etc.; Finance and insurance activities are well established sectors with favorable opportunities for development in Bulgaria. Over the years until the end of the period, the state of the total output gap of GVA is driven mainly by Wholesale and retail trade, which also includes Land and pipeline transport; Financial and insurance activities and Manufacturing. Having in mind that exports had a significant contribution to the recovery, it makes sense that some of the Manufacturing industries and transport to EU and non-EU countries are leading among the sectors. This is also broadly in line with some previous conclusions stating that in general, Services have the main contribution to the GVA growth in the period 2000-2017 and is the only sector that has a positive contribution in 2009 and 2010 (Raleva, S., 2019).

Obviously, some sectors, especially in services, are much more flexible and are able to recover quickly from negative shocks. The recovery of other sectors like Construction and Real estate services requires much more time due to their higher investment needs. It is noticeable that capital-intensive sectors enter the area below the potential a little slower, but also recover much more slowly. Since the negative shock to the economy has led to the bankruptcy of some companies in the sector, the large capital requirements for starting a new business in these industries are in fact a barrier to entry and respectively for the recovery of those sectors.

\section{Conclusion}

The HP filtering approach, presented good results for obtaining the potential output on a sectoral level and allowed to draw some
Sectoral Output Gaps - Estimates for Bulgaria

interesting conclusions. As a result of the applied procedure, it was found that the individual sectors show a different trend of potential development. While the level of potential output in some sectors such as Construction; Financial and insurance activities shows a retention after 2008-2009, others such as Wholesale and retail trade, transport, accommodation and food service activities; Information and communication services and in some sense Manufacturing maintain a stable positive development trend. Although the potential of Agricultural sector has been declining for most of the period, it seems to be reversing by the end of it. This means that the changes in the structure of GVA are the result not only of cyclical factors, but also of fundamental changes pushing the economy towards quality upgrading. At the same time, some industries like Arts, entertainment and recreation are much more volatile than others, and the deviation from their potential can often vary from positive to negative. This shows some instability, which could lead to a sudden collapse of the entire sector. Through connectivity with other sectors, this could trigger a general economic crisis. However, the results show that such a spillover of negative shocks rarely has a severe effect on the whole economy and strongly depends on the size and characteristics of the sector as consumer or/and producer of output for the others. On the contrary, often the negative gap in one sector is compensated by a positive one in another, so that the overall deviation from the potential output is much more stable over time. It should be borne in mind here that the Bulgarian economy is relatively diversified and these findings show a low inter-sectoral connectivity. In other countries, relying mainly on natural resources or tourism, for example, the results would be significantly different. The highly positive output gap of the total 


\section{Articles}

GVA before 2009 was mainly driven by the overheating in Manufacturing; Wholesale and retail trade, transport, etc.; Professional services and Real estate activities. The same sectors, without Professional services, turn the state of the output gap from positive to negative, which suggests their fundamental status for the overall development of the economy. In contrast, the behavior of the Arts, entertainment and recreation; Construction and to some extent Information and communication services shows they are more like followers of the overall state of the business cycle. Contrary to expectations, Finance and insurance activities made a relatively small contribution to the negative output gap of the total GVA in 2009, as they quickly returned to positive territory. The Agriculture is showing quite different activity from that of other industries, and due to its declining share in the structure of GVA, even a significant shock in the sector will have a modest effect on the overall business cycle phase.

The general conclusion of the study is that sectoral output gaps offer a new and interesting perspective on the economy. It proposes to understand not only the quantitative but also the qualitative development of the economy. This is especially important in the modern age of transition to the information society, and therefore research in this area needs to be accelerated.

\section{References}

Aaron G. Grech, 2014. Investigating potential output using the Hodrick-Prescott filter: an application for Malta, CBM Working Papers WP/02/2014, Central Bank of Malta.

Alichi, A., 2015., A New Methodology for Estimating the Output Gap in the United States, Working Paper WP/15/144, International Monetary Fund.
Arabic, V., 2014. CENSUS-X12: Eviews program for automatic seasonal adjustment, EFZG Department of Macroeconomics Software Series 14-01, Faculty of Economics and Business, University of Zagreb.

Cerra, V., and S.C. Saxena, 2000. Alternative Methods of Estimating Potential Output and the Output Gap: An Application to Sweden, IMF Working Paper 00/59.

Clark, C., 1957. The Conditions of Economic Progress, 3rd ed., London: Macmillan.

De Masi, P. R., 1997. IMF estimates of potential output: Theory and practice, Working Paper WP/97/177, International Monetary Fund.

Dietrich, A., \& Krüger, J., 2008. Long-Run Sectoral Development - Time Series Evidence for the German Economy, Jena Economic Research Papers 2008-013, FriedrichSchiller-University Jena.

Eulfis, 2018. A Practitioner's Guide to Potential Output and the Output Gap (Tech. Rep.). Fantino, D., 2018, November. Potential output and microeconomic heterogeneity (Temi di discussione (Working papers) No. 1194). Bank of Italy, Economic Research and International Relations Area.

Ganev, K., 2005. Measuring total factor productivity: accounting for Bulgaria's economic growth, Discussion papers, № 48, BNB, pp. 14-15. (in Bulgarian)

Giorno, C., et al., 1995, Estimating Potential Output, Output Gaps and Structural Budget Balances, OECD Economics Department Working Papers, No. 152, OECD Publishing, Paris, https://doi.org/10.1787/533876774515.

Giovanni Dell'Ariccia \& Ehsan Ebrahimy \& Deniz O Igan \& Damien Puy, 2020. Discerning Good from Bad Credit Booms; The Role of Construction, IMF Staff Discussion Notes 2020/002, International Monetary Fund.

Hodrick, R.J., and E.C. Prescott, 1997. PostWar U.S. Business Cycles: An Empirical 
Investigation, Journal of Money, Credit and Banking, Vol. 29(1), pp. 1-16.

Kolev, K., 2020. Analysis of gross added value by economic activities in Bulgaria and EU-28, Conference: Economic development and policies - realities and prospects, Sofia, 21-22 November, BAS, Prof. Marin Drinov Academic Publishing House, pp. 127-134.

Ladiray, D., Mazzi, G. L., Sartori, F., 2003. Statistical methods for potential output estimation and cycle extraction, Working Papers and Studies, Office for Official Publications of the European Communities, Luxembourg.

Minassian, G., 2017. Economics of the inputoutput relations, Economic Thought Journal, issue 3, pp. 30-53.

Ngai, L.R., Pissarides, C.A., 2007. Structural Change in a Multi-Sector Model of Growth, The American Economic Review, vol. 97, pp. 429-443.

Okun, A., 1962. Potential GDP: Its Measurement and Significance, American Statistical Association, Proceedings of the Business and Economic Statistics Section, Washington.
Pirimova, V., 2014. Cyclic recurrence in the economy: forms, sources, mechanisms, Bulgaria: Publishing Complex of the University of National and World Economy, Sofia. (in Bulgarian)

Pirimova, V., and Sotirova, E., 2018. SectorIndustrial Crisis Instability and Resumption of Growth in the Bulgarian Economy, Ikonomiceski i Sotsialni Alternativi, issue 2, pp. 5-19. (in Bulgarian)

Raleva, S., 2019. Structural Characteristics of Economic Growth in Bulgaria, Nauchni trudove, University of National and World Economy, Sofia, Bulgaria, issue 5, December, p. 65-81. (in Bulgarian)

Scacciavillani, F., \& Swagel, P., 1999. Measures of potential output: An application to Israel, Working Paper WP/99/96, International Monetary Fund.

St-Amant P. \& S. van Norden, 1997, Measurement of the output gap: A discussion of recent research at the Bank of Canada, Technical Report No.79, Bank of Canada.

Todorov, I., \& Aleksandrov, A., 2018. Two combined approaches to estimating Bulgaria's cyclical position and business cycle phase, Electronic magazine "Dialogue" (3), pp. 1-10. (in Bulgarian) 


\section{Articles}

\section{Appendix}

Table 3. Sectoral potential output, in mln. euro

\begin{tabular}{|c|c|c|c|c|c|c|c|c|c|c|c|c|}
\hline Year/ Sector & A & B-E & C & $\mathbf{F}$ & G-I & $\mathbf{J}$ & K & L & M_N & $0-Q$ & $\mathbf{R}-\mathbf{U}$ & GVA \\
\hline $2000 Q 1$ & 674.5 & 1293.7 & 744.8 & 274.5 & 1067.6 & 139.2 & 87.5 & 690.5 & 310.0 & 1249.1 & 90.5 & 5877.1 \\
\hline 200002 & 671.9 & 1318.9 & 762.7 & 276.6 & 1087.9 & 144.6 & 95.9 & 694.0 & 314.6 & 1251.3 & 91.4 & 5947.0 \\
\hline $2000 Q 3$ & 669.6 & 1344.0 & 780.5 & 278.8 & 1108.4 & 150.0 & 104.5 & 697.6 & 319.4 & 1253.4 & 92.2 & 6017.9 \\
\hline $2000 Q 4$ & 667.6 & 1369.2 & 798.3 & 281.1 & 1129.1 & 155.3 & 113.2 & 701.3 & 324.5 & 1255.3 & 93.1 & 6089.8 \\
\hline $2001 Q 1$ & 666.0 & 1394.4 & 816.1 & 283.6 & 1150.0 & 160.5 & 122.2 & & 330.0 & & 94.1 & 163.2 \\
\hline $2001 Q 2$ & 664.6 & 1419.5 & 834.0 & 286.2 & 1171.1 & 165.6 & 131.5 & 709.8 & 335.6 & 1259.1 & 95.1 & 6238.0 \\
\hline 200103 & 663.4 & 1444.7 & 851.9 & 289.0 & 1192.5 & 170.6 & 141.1 & 714.5 & 341.6 & 1261.0 & 96.2 & 314.6 \\
\hline $2001 Q 4$ & 662.5 & 1469.9 & 870.0 & 292.0 & 1214.3 & 175.5 & 151.1 & 719.7 & 347.7 & 1262.9 & 7.4 & 393.0 \\
\hline $2002 Q 1$ & 661.7 & 1495.2 & 888.2 & 295.2 & 1236.3 & 180.3 & 161.5 & 725.3 & 354.0 & & 8.7 & 473.3 \\
\hline $2002 Q 2$ & 660.8 & 1520.7 & 906.7 & 298.7 & 1258.7 & 185.0 & 172.4 & 731.2 & 360.6 & 1267.2 & 100.2 & 6555.5 \\
\hline $2002 Q 3$ & 659.9 & 1546.2 & 925.3 & 302.5 & 1281.5 & 189.5 & 183.7 & 737.3 & 367.3 & 1269.6 & 101.9 & 6639.5 \\
\hline $2002 Q 4$ & 658.9 & 1571.8 & 944.1 & 306.7 & 1304.8 & 194.1 & 195.5 & 743.5 & 374.3 & & & 725.5 \\
\hline 200301 & 657.6 & 1597.4 & 963.2 & 311.3 & 1328.4 & 198.5 & 207.9 & 750.0 & & & & 6813.5 \\
\hline $2003 Q 2$ & 656.1 & 1623.1 & 982.5 & 316.3 & 1352.5 & 203.0 & 220.8 & 756.6 & 389.3 & 1277.9 & 107.9 & 6903.6 \\
\hline $2003 Q 3$ & 654.2 & 1648.8 & 1002.0 & 321.8 & 1377.0 & 207.6 & 234.2 & 763.6 & 397.3 & 1281.1 & 110.3 & 6995.9 \\
\hline $2003 Q 4$ & 651.9 & 1674.4 & 1021.6 & 327.8 & 1401.9 & 212.3 & 248.2 & 770.7 & 405.6 & 1284.6 & 112.9 & 7090.3 \\
\hline $2004 Q 1$ & 649.1 & 1699.9 & 1041.3 & 334.3 & 1427.1 & 217.1 & 262.8 & 778.2 & 414.2 & 1288.4 & 115.8 & 7186.9 \\
\hline $2004 Q 2$ & 645.8 & 1725.2 & 1061.2 & 341.4 & 1452.6 & 222.2 & 277.9 & 785.9 & 423.1 & 1292.5 & 119.0 & 7285.6 \\
\hline $2004 Q 3$ & & 1750.4 & & & & 227.6 & & & & & & 386.1 \\
\hline $2004 Q 4$ & 637.6 & 1775.5 & 1101.2 & 357.1 & 1503.6 & 233.5 & 309.8 & 802.2 & 41.0 & & 126.0 & 488.3 \\
\hline $2005 Q 1$ & 632.5 & 1800.2 & 1121.2 & 365.8 & 1529.0 & 239.8 & 326.6 & 810.6 & 451.1 & 1306.3 & 129.9 & 7591.7 \\
\hline $2005 Q 2$ & 627.0 & 1824.6 & 1141.1 & 374.9 & 1553.9 & 246.6 & 343.9 & 819.0 & 460.7 & 1311.2 & 134.0 & 7695.9 \\
\hline $2005 Q 3$ & 621.0 & 1848.5 & 1160.8 & 384.4 & 1578.2 & 254.1 & 361.8 & 827.4 & 470.4 & 1316.2 & 138.3 & 7800.4 \\
\hline $2005 Q 4$ & 614.6 & 1871.9 & 1180.1 & 394.2 & 1601.8 & 262.3 & 380.1 & 835.7 & 480.1 & 1321.1 & 142.9 & 7904.7 \\
\hline $2006 Q 1$ & 607.9 & 1894.5 & 1198.9 & 404.3 & 1624.5 & 271.1 & 398.9 & 8136 & 489.6 & 1326.0 & & 8008.2 \\
\hline $2006 Q 2$ & 600.9 & 1916.2 & 1216.9 & & 1646.1 & 280.8 & & & & & & 8110.2 \\
\hline $2006 Q 3$ & 593.8 & 1936.7 & 1233.9 & 424.7 & 1666.6 & & & & & & & 8210.0 \\
\hline $2006 Q 4$ & 586.5 & 1955.8 & 1249.8 & 434.8 & 1685.7 & 302.1 & 458.0 & 864.9 & 515.7 & 1340.2 & 163.1 & 8306.9 \\
\hline $2007 Q 1$ & 579.2 & 1973.3 & 1264.4 & 444.6 & 1703.6 & 313.7 & 478.3 & 870.9 & 523.4 & 1344.8 & 168.5 & 8400.2 \\
\hline $2007 Q 2$ & 572.1 & 1988.9 & 1277.3 & 454.0 & 1720.3 & 325.9 & 498.7 & 876.1 & 30.3 & 9.2 & 173.8 & 8489.3 \\
\hline $2007 Q 3$ & 565.4 & 2002.4 & 1288.5 & 462.8 & 1735.6 & 338.4 & 519.1 & 880.6 & 536.5 & 1353.6 & 179.2 & 8573.7 \\
\hline $2007 Q 4$ & 559.1 & 2013.9 & 1297.7 & 470.8 & 1749.8 & 351.2 & 539.3 & 884.5 & 541.9 & 1357.9 & 184.4 & 8652.9 \\
\hline $2008 Q 1$ & 553.1 & 2023.1 & 1305.1 & 478.0 & 1763.1 & 364.1 & 559.3 & 887.8 & 546.4 & 1362.1 & 189.5 & 8726.4 \\
\hline $2008 Q 2$ & 547.5 & 2030.2 & 1310.6 & 484.1 & 1775.6 & 376.7 & 578.9 & 890.5 & 550.2 & 1366.1 & 194.3 & 8794.1 \\
\hline $2008 Q 3$ & 542.0 & 2035.4 & 1314.5 & 489.0 & 1787.6 & 388.9 & 597.9 & 892.7 & 553.4 & 1370.1 & 198.8 & 8855.8 \\
\hline
\end{tabular}




\begin{tabular}{|c|c|c|c|c|c|c|c|c|c|c|c|c|}
\hline Year/s & A & B-E & C & $\mathbf{F}$ & G-I & $\mathbf{J}$ & K & L & M_N & $0-Q$ & R-U & GVA \\
\hline $2008 Q 4$ & 536.6 & 2039.0 & 1316.9 & 492.8 & 1799.3 & 400.5 & 616.3 & 894.6 & 555.9 & 1373.8 & 203.0 & 8911.7 \\
\hline 200901 & 531.2 & 2041.4 & 1318.2 & 495.2 & 1811.0 & 411.4 & 633.8 & 896.2 & 557.9 & 1377.2 & 206.8 & 8962.2 \\
\hline 200902 & 525.9 & 2043.0 & 1318.7 & 496.2 & 1822.8 & 421.7 & 650.4 & 897.6 & 559.4 & 1380.4 & 210.2 & 9007.7 \\
\hline 200903 & 520.6 & 2044.2 & 1318.7 & 496.0 & 1835.1 & 431.2 & 665.9 & 898.8 & 560.5 & 1383.2 & 13.2 & 9048.7 \\
\hline $2009 Q 4$ & 515.5 & 2045.3 & 1318.5 & 494.7 & 1847.9 & 440.0 & 680.2 & 900.0 & & 1385.5 & 15.7 & 9085.9 \\
\hline 20100 & 510.4 & 2046.6 & 1318.5 & 492.4 & 1861.2 & 448.1 & 693.1 & 01.2 & 61.4 & 87.4 & 217.9 & 9119.7 \\
\hline $2010 Q 2$ & 505.7 & 2048.5 & 1319.0 & 489.3 & 1874 & 455 & 704.4 & 902.3 & & 3.8 & 19.8 & 150.8 \\
\hline $2010 Q 3$ & 01.1 & 2051.2 & 1320.2 & 485.6 & 1888.8 & 462.4 & 714.1 & 903.6 & 561.5 & 1389.7 & 21.4 & 179.3 \\
\hline $2010 Q 4$ & 496.9 & 2054.7 & 1322.1 & 481.4 & 1902.9 & 468.6 & 722.1 & 904.9 & 561.4 & 1390.2 & 222.7 & 9205.8 \\
\hline 201101 & 493.0 & 2059.2 & 1324.8 & 476.9 & 1916.9 & 1744 & 728.4 & 906.3 & 561.3 & 1390.4 & 223.7 & 9230.6 \\
\hline $2011 Q 2$ & 489.3 & 2064.7 & 1328.4 & 472.3 & 1931.0 & 479.6 & 733.2 & & & & & 9254.1 \\
\hline $2011 Q 3$ & 486.0 & 2071.1 & 1332.7 & 467.4 & & & & 909.6 & & & & 9276.5 \\
\hline $2011 Q 4$ & 483.0 & 2078.6 & 1337.9 & 462.6 & 1958.9 & 488.7 & 738.2 & (111.J & & & 225.7 & 9298.6 \\
\hline $2012 Q 1$ & 480.4 & 2087.0 & 1344.0 & 457.9 & 1972.9 & 492.7 & 738.8 & 913.6 & 562.0 & 389.6 & 26.1 & 9320.8 \\
\hline $2012 Q 2$ & 478.2 & 2096.5 & 1351.0 & 453.2 & 1986.9 & 496.5 & 738.3 & 915.8 & 562.7 & 1389.3 & 26.5 & 9344.0 \\
\hline $2012 Q 3$ & 476.4 & 2107.0 & 1358.8 & 448.7 & 2001.1 & 500.2 & 37.0 & 918.4 & 563.8 & 1389.2 & 226.9 & 9368.6 \\
\hline $2012 Q 4$ & 475.0 & 2118.5 & 1367.5 & 444.5 & 2015.4 & 503.8 & 735.0 & 921.2 & 565.3 & 1389.2 & 227.3 & 9395.3 \\
\hline 201301 & & 2131.1 & & 440.6 & & & & & & & & 424.7 \\
\hline $2013 Q 2$ & & 2144.7 & 1387.9 & 436.9 & & & & & & & & 457.4 \\
\hline 201303 & 473.6 & 2159.4 & 1399.8 & 433.6 & 2059.5 & 515.3 & 7 & 9 & & & & 9493.9 \\
\hline $2013 Q 4$ & 474.0 & 2175.2 & 1412.8 & 430.6 & 2074.5 & 519.6 & 7 & & & & & 9534.5 \\
\hline $2014 Q 1$ & 474.7 & 2191.9 & 1426.9 & 427.9 & 2089.8 & 524 & 721 & 943 & .9 & & 2.0 & 579.4 \\
\hline $2014 Q 2$ & 475.8 & 2209.5 & 1442.0 & 425.6 & 2105.3 & 529.6 & 719.4 & 949.8 & 583.0 & & 233.4 & 9628.9 \\
\hline $2014 Q 3$ & 477.1 & 2227.9 & 1458.2 & 423.6 & 2121.1 & 535.3 & & 0571 & & & & 9682.8 \\
\hline $2014 Q 4$ & & 2247.0 & 1475.3 & 421.9 & & & & & & & & 9741.3 \\
\hline $2015 Q 1$ & 480.7 & 2266.6 & 1493.2 & 420.5 & & & & & & & & 9804.0 \\
\hline $2015 Q 2$ & & & & & & & & & & & & 9870.9 \\
\hline $2015 Q 3$ & & 2306.9 & & & & & & & & & & 9941.7 \\
\hline $2015 Q 4$ & & 27.3 & & 418.0 & & & 17.0 & & & & 44.6 & 0016.0 \\
\hline $2016 Q 1$ & 491.8 & 2347.5 & 1570.6 & 417.6 & 2217.7 & 582.3 & 718.7 & 1021.6 & 620.7 & 1429.3 & 246.7 & 10093.8 \\
\hline $2016 Q 2$ & 495.3 & 2367.4 & 1590.8 & 417.4 & 2233.7 & 592.2 & 720.9 & 1035.9 & 627.0 & 1436.0 & 248.8 & 10174.6 \\
\hline $2016 Q 3$ & 499.1 & 2386.9 & 1611.3 & 417.5 & 2249.7 & 602.5 & 723.6 & 1051.1 & 633.5 & 1443.3 & 251.0 & 10258.2 \\
\hline $2016 Q 4$ & 503.1 & 2405.8 & 1631.9 & 417.8 & 2265.6 & 613.2 & 726.7 & 1067.2 & 640.1 & & 253.3 & 10344.0 \\
\hline & & 2424.0 & 1652.6 & 418.3 & 2281.4 & & & & & & 255.5 & 10431.9 \\
\hline $2017 Q 2$ & & 2441.5 & 1673.3 & 418.9 & 2297.0 & 635.7 & 734.2 & 1102.0 & 653.9 & 1469.0 & 257.8 & 10521.5 \\
\hline $2017 Q 3$ & 515.5 & 2458.4 & 1694.0 & 419.8 & 2312.6 & 647.3 & 738.5 & 1120.5 & 61.0 & 1478.6 & 260.1 & 10612.3 \\
\hline $2017 Q 4$ & & 2474.5 & 1714.8 & 420.7 & 2328.0 & & & 1139.6 & 668.3 & 1488.7 & 262.4 & 10704.2 \\
\hline 201801 & 524.0 & 2490.1 & 1735.6 & 421.8 & 2343.2 & 671.1 & 748.0 & 1159.2 & 675.7 & 1499.2 & 264.7 & 10797.0 \\
\hline
\end{tabular}




\section{Articles}

\begin{tabular}{|lcccccccccccc|}
\hline Year/ Sector & A & B-E & C & F & G-I & J & K & L & M_N & O-Q & R-U & GVA \\
\hline $2018 Q 2$ & 528.2 & 2505.3 & 1756.5 & 423.0 & 2358.2 & 683.2 & 753.2 & 1179.2 & 683.2 & 1510.0 & 267.0 & 10890.4 \\
\hline 201803 & 532.4 & 2520.2 & 1777.4 & 424.3 & 2372.9 & 695.3 & 758.5 & 1199.5 & 690.7 & 1521.1 & 269.3 & 10984.3 \\
\hline $2018 Q 4$ & 536.6 & 2534.9 & 1798.3 & 425.7 & 2387.5 & 707.4 & 764.0 & 1220.0 & 698.2 & 1532.4 & 271.6 & 11078.4 \\
\hline 201901 & 540.9 & 2549.6 & 1819.2 & 427.1 & 2401.9 & 719.5 & 769.6 & 1240.6 & 705.8 & 1543.8 & 273.9 & 11172.8 \\
\hline $2019 Q 2$ & 545.2 & 2564.2 & 1840.0 & 428.5 & 2416.2 & 731.6 & 775.3 & 1261.3 & 713.4 & 1555.4 & 276.2 & 11267.3 \\
\hline 201903 & 549.5 & 2578.9 & 1860.6 & 429.9 & 2430.3 & 743.7 & 781.1 & 1282.1 & 720.9 & 1567.0 & 278.5 & 11361.9 \\
\hline 201904 & 553.8 & 2593.6 & 1881.2 & 431.4 & 2444.4 & 755.8 & 786.8 & 1302.8 & 728.5 & 1578.6 & 280.8 & 11456.5 \\
\hline
\end{tabular}

Source: Own calculations based on Eurostat, National Accounts (ESA 2010) data

*The represented sectors are as follows:

A Agriculture, forestry and fishing

B-E Industry (except construction)

C Manufacturing

F Construction

G-I Wholesale and retail trade, transport, accommodation and food service activities

$\mathrm{J}$ Information and communication

$\mathrm{K} \quad$ Financial and insurance activities

L Real estate activities

M_N Professional, scientific and technical activities; administrative and support service activities

O-Q Public administration, defence, education, human health and social work activities

R-U Arts, entertainment and recreation; other service activities; activities of household and extra-territorial organizations and bodies

GVA Total Gross Value Added in the economy

Table 4. Sectoral output gaps, in \%

\begin{tabular}{|lrrrrrrrrrrrr|}
\hline Year/ Sector & A & B-E & \multicolumn{1}{l}{ C } & F & G-I & J & \multicolumn{1}{l}{ K } & \multicolumn{1}{l}{ L } & M_N & O-Q & R-U & GVA \\
\hline $2000 Q 1$ & -1.6 & 2.8 & 6.3 & 1.5 & -0.7 & -9.3 & 4.4 & 0.6 & 1.0 & 5.2 & -5.0 & 1.4 \\
\hline $2000 Q 2$ & -5.5 & 5.7 & 8.0 & 0.8 & 1.8 & 0.3 & 8.4 & -1.5 & 12.2 & -4.1 & 14.7 & 1.0 \\
\hline $2000 Q 3$ & -10.3 & 2.7 & 1.8 & -0.7 & -2.4 & -2.9 & 8.3 & 8.3 & -28.9 & 3.7 & 1.5 & -0.7 \\
\hline $2000 Q 4$ & -5.3 & -0.6 & -0.2 & 0.6 & -0.5 & 8.0 & 4.3 & -8.7 & 2.9 & 1.1 & 21.1 & -0.8 \\
\hline $2001 Q 1$ & -3.4 & 1.3 & 0.6 & 1.6 & 2.3 & 2.8 & -17.9 & -1.1 & -1.7 & 0.6 & -8.1 & -0.1 \\
\hline $2001 Q 2$ & -5.1 & 1.0 & 0.7 & 1.5 & 2.3 & 4.1 & -6.3 & -6.0 & -12.8 & 0.0 & 1.3 & -1.2 \\
\hline $2001 Q 3$ & -5.4 & 0.5 & 0.5 & 2.8 & -4.7 & 4.0 & 1.3 & -11.4 & 6.3 & 0.9 & -2.0 & -1.9 \\
\hline $2001 Q 4$ & -2.5 & -1.2 & -1.7 & 2.8 & 1.5 & 3.6 & -1.1 & -11.7 & 25.4 & -8.5 & -15.7 & -1.9 \\
\hline $2002 Q 1$ & -0.7 & -3.6 & -3.5 & 0.3 & 0.8 & 12.8 & 2.5 & -4.5 & 16.0 & 1.4 & 22.5 & 0.7 \\
\hline $2002 Q 2$ & 1.7 & -1.5 & 0.0 & 1.7 & 0.1 & 7.3 & -9.9 & 9.9 & -16.2 & 5.0 & -2.2 & 1.0 \\
\hline $2002 Q 3$ & 5.1 & 0.4 & 0.0 & 0.5 & -1.2 & 9.9 & -7.8 & 8.2 & 7.0 & -1.0 & -14.6 & 1.3 \\
\hline $2002 Q 4$ & 0.0 & 0.2 & -2.7 & -0.2 & -3.3 & 3.9 & -4.7 & 12.5 & -10.4 & -1.9 & -12.7 & -0.4 \\
\hline $2003 Q 1$ & 0.6 & -2.3 & -3.0 & -1.0 & 0.4 & 7.3 & -4.5 & -1.1 & -7.3 & -0.4 & 19.1 & -0.7 \\
\hline $2003 Q 2$ & 1.9 & -1.7 & -3.0 & -3.6 & -4.0 & 6.4 & 3.4 & -5.3 & 2.3 & 1.4 & 10.7 & -0.9 \\
\hline $2003 Q 3$ & -1.6 & 1.5 & 0.8 & -5.6 & -3.9 & 2.1 & 0.5 & -1.0 & -1.3 & -1.7 & -5.3 & -1.3 \\
\hline $2003 Q 4$ & 2.5 & 4.3 & 8.9 & -5.9 & -4.2 & -0.7 & -1.3 & -0.9 & -4.6 & -1.3 & -23.6 & -0.9 \\
\hline
\end{tabular}


Articles

Sectoral Output Gaps - Estimates for Bulgaria

\begin{tabular}{|c|c|c|c|c|c|c|c|c|c|c|c|c|}
\hline Year/ Sector & A & $B-E$ & C & $\mathbf{F}$ & G-I & $\mathbf{J}$ & K & $\mathbf{L}$ & M_N & $0-Q$ & $R-U$ & GVA \\
\hline $2004 Q 1$ & 1.8 & -2.9 & -6.4 & -3.5 & -2.3 & 7.8 & 2.6 & -1.7 & -13.2 & -2.6 & -16.6 & -2.5 \\
\hline $2004 Q 2$ & 3.6 & -2.4 & -5.0 & -4.8 & -0.3 & 7.8 & -12.0 & -8.0 & 3.3 & -3.7 & -0.6 & -2.1 \\
\hline $2004 Q 3$ & 9.7 & -1.7 & -4.5 & -6.7 & -1.1 & 4.5 & -7.0 & -9.3 & 0.0 & 0.9 & 14.7 & -0.8 \\
\hline $2004 Q 4$ & 11.8 & 0.3 & -0.2 & -11.4 & -7.1 & -6.2 & -4.1 & -3.8 & -3.2 & -4.1 & 1.4 & -2.5 \\
\hline $2005 Q 1$ & 0.8 & -0.7 & -2.3 & -2.0 & 0.8 & -10.7 & 6.3 & -0.1 & -9.2 & -1.0 & -14.5 & -1.1 \\
\hline $2005 Q 2$ & -0.1 & -4.2 & -5.5 & -7.4 & 2.2 & -9.0 & 7.7 & 0.0 & -11.0 & 3.0 & 1.8 & -1.0 \\
\hline 200503 & 3.7 & -6.6 & -7.8 & -6.4 & 3.2 & -9.1 & -3.8 & 1.3 & -7.2 & 2.5 & 1.6 & -1.3 \\
\hline $2005 Q 4$ & 0.4 & -0.5 & 0.8 & -11.2 & 0.5 & -12.2 & -10.5 & -1.4 & 0.3 & 1.1 & -6.4 & -1.5 \\
\hline $2006 Q 1$ & 0.0 & 0.9 & 0.3 & -6.0 & 1.4 & -14.1 & -7.7 & 0.3 & 9.5 & 1.9 & -17.2 & -0.1 \\
\hline $2006 Q 2$ & 1.1 & -1.3 & -2.1 & -2.2 & 4.2 & -16.1 & -7.6 & 2.5 & 4.5 & 0.9 & -23.4 & -0.2 \\
\hline $2006 Q 3$ & 9.8 & -1.5 & -2.4 & -3.3 & 5.7 & -14.4 & -8.8 & 3.4 & -3.0 & -1.6 & -7.6 & 0.1 \\
\hline $2006 Q 4$ & 8.6 & -0.9 & 0.8 & -3.3 & 2.7 & -12.3 & -7.8 & 7.1 & -5.3 & 4.0 & 8.4 & 1.1 \\
\hline $2007 Q 1$ & 2.3 & 6.0 & 6.1 & -2.6 & 2.1 & -20.4 & -8.6 & 5.2 & 5.9 & -0.4 & -3.7 & 1.4 \\
\hline $2007 Q 2$ & -2.6 & 4.4 & 7.8 & 0.6 & 7.5 & -21.2 & -1.2 & 4.6 & 21.5 & -3.9 & -13.9 & 2.4 \\
\hline $2007 Q 3$ & -58.6 & 5.7 & 9.3 & 2.9 & 7.4 & -18.0 & 9.1 & 3.4 & 6.5 & -0.2 & 0.2 & -0.3 \\
\hline $2007 Q 4$ & -20.5 & 8.7 & 11.3 & 5.0 & 4.4 & -19.0 & 6.0 & 7.2 & 12.5 & 3.1 & -8.2 & 3.3 \\
\hline $2008 Q 1$ & 3.5 & 11.9 & 13.7 & 5.6 & -1.4 & 19.5 & -12.0 & 5.3 & 11.2 & -2.7 & 17.5 & 4.2 \\
\hline $2008 Q 2$ & 14.6 & 9.4 & 10.4 & 5.7 & 0.6 & 22.7 & -0.9 & -2.5 & -1.4 & -6.2 & 8.8 & 3.3 \\
\hline $2008 Q 3$ & 9.9 & 3.7 & 6.7 & 10.5 & 0.1 & 25.1 & -1.0 & 1.2 & 1.1 & -2.0 & 8.8 & 3.2 \\
\hline $2008 Q 4$ & 11.8 & 1.7 & 3.0 & 18.9 & -2.3 & 19.9 & 2.3 & -11.1 & -13.8 & 9.7 & 17.2 & 2.6 \\
\hline 200901 & 4.5 & -3.4 & -2.6 & 25.0 & 7.1 & 4.1 & 0.1 & 7.0 & -7.5 & -8.6 & -0.8 & 1.4 \\
\hline $2009 Q 2$ & 6.6 & -5.3 & -2.5 & 19.8 & -13.7 & 21.1 & 0.0 & 2.9 & 13.7 & 1.7 & 17.8 & 0.3 \\
\hline $2009 Q 3$ & 6.0 & 6.6 & 8.9 & 14.5 & -16.2 & 1.5 & -5.4 & -3.1 & 16.0 & 2.5 & 7.6 & 0.3 \\
\hline 200904 & -0.3 & -4.4 & -10.5 & 2.2 & -7.5 & 0.1 & -0.7 & -13.1 & -1.5 & 3.6 & 27.7 & -2.6 \\
\hline 201001 & -3.7 & -9.0 & -10.3 & -6.4 & 5.8 & -2.0 & 16.9 & 3.5 & -13.3 & 3.3 & -12.1 & -0.5 \\
\hline $2010 Q 2$ & -4.6 & -6.5 & -8.9 & 4.7 & -7.1 & 10.8 & 14.1 & 3.8 & 1.3 & 6.6 & -13.0 & -0.2 \\
\hline 201003 & -6.1 & -4.8 & -8.5 & -20.2 & 5.1 & -5.8 & 12.3 & 1.0 & 0.2 & 1.6 & -7.1 & -0.6 \\
\hline $2010 Q 4$ & -4.5 & -5.9 & -10.2 & 4.4 & 4.4 & -5.5 & 11.8 & -3.7 & 1.9 & -3.2 & 1.5 & -0.5 \\
\hline 201101 & 1.8 & -0.3 & 5.9 & -7.2 & 2.8 & 6.7 & -8.8 & -4.1 & 1.6 & 1.6 & 20.3 & 0.3 \\
\hline 201102 & -0.2 & 7.2 & 3.0 & -6.1 & 3.7 & 6.9 & 18.8 & 1.1 & -10.4 & 1.7 & 13.3 & 4.0 \\
\hline 201103 & 11.0 & -2.9 & -0.6 & -7.5 & 2.8 & 7.8 & 9.8 & 1.2 & -2.5 & 1.6 & -4.6 & 1.4 \\
\hline $2011 Q 4$ & 3.8 & -5.4 & -7.5 & 2.3 & -0.5 & 3.9 & 5.0 & 3.4 & 12.0 & -8.0 & -11.4 & -0.8 \\
\hline $2012 Q 1$ & -1.0 & 0.5 & 2.4 & -3.4 & -2.2 & -2.8 & 0.4 & 1.4 & -2.5 & 1.7 & 8.7 & -0.2 \\
\hline $2012 Q 2$ & -8.9 & 5.4 & 7.4 & -1.8 & -0.6 & -0.6 & -4.1 & 3.6 & -8.0 & 3.2 & 6.9 & 0.7 \\
\hline $2012 Q 3$ & -11.3 & -1.4 & 2.6 & -5.7 & -0.3 & 1.3 & 5.8 & 2.6 & -4.4 & 1.9 & 4.5 & -0.3 \\
\hline $2012 Q 4$ & -1.2 & -1.4 & 0.1 & -9.0 & 0.0 & 0.1 & 1.2 & 2.1 & -0.2 & 2.1 & -34.2 & -1.0 \\
\hline $2013 Q 1$ & 1.6 & -1.5 & -4.2 & 0.2 & 0.1 & -2.1 & -5.1 & -1.3 & -2.8 & -4.5 & -7.9 & -1.9 \\
\hline $2013 Q 2$ & -1.0 & -0.6 & -1.8 & 0.2 & -0.8 & -1.7 & -4.9 & -0.7 & -2.4 & -4.8 & -5.1 & -1.9 \\
\hline
\end{tabular}




\section{Articles}

\begin{tabular}{|c|c|c|c|c|c|c|c|c|c|c|c|c|}
\hline Year/ Sector & A & B-E & C & $\mathbf{F}$ & G-I & $J$ & K & $\mathbf{L}$ & M_N & $0-Q$ & $R-U$ & GVA \\
\hline $2013 Q 3$ & -5.5 & -2.6 & -5.6 & -1.6 & 0.1 & 0.7 & -5.7 & -1.0 & -1.7 & -1.7 & 1.6 & -1.7 \\
\hline $2013 Q 4$ & -1.6 & -1.6 & -1.1 & -4.3 & 0.9 & -2.2 & -5.8 & -1.3 & -0.5 & -1.5 & -2.4 & -1.4 \\
\hline $2014 Q 1$ & 2.8 & -1.7 & -4.2 & -2.8 & -2.3 & -3.6 & -4.3 & -0.6 & -2.1 & -0.6 & -10.3 & -1.9 \\
\hline $2014 Q 2$ & 8.1 & -2.2 & -3.5 & -3.5 & -0.4 & -5.3 & -1.5 & -3.4 & -4.0 & -0.2 & -5.3 & -1.5 \\
\hline $2014 Q 3$ & 1.1 & -0.8 & -2.0 & -2.4 & -3.3 & -4.3 & -6.1 & -1.3 & -3.3 & -2.0 & 1.2 & -2.2 \\
\hline $2014 Q 4$ & 6.6 & 1.0 & 5.7 & -0.4 & -2.6 & -3.5 & -4.7 & 0.4 & -3.1 & 4.1 & 1.8 & -0.1 \\
\hline $2015 Q 1$ & 0.3 & -2.6 & -7.6 & -0.2 & 0.9 & -3.2 & -2.6 & -2.6 & 1.9 & 1.2 & -0.5 & -0.7 \\
\hline $2015 Q 2$ & -0.8 & -0.4 & -0.9 & -0.1 & 2.9 & -7.4 & -7.4 & -2.6 & 1.5 & 0.6 & 4.4 & -0.4 \\
\hline $2015 Q 3$ & -13.9 & 0.7 & 4.8 & 4.7 & 3.8 & -5.5 & -4.6 & -1.0 & 3.0 & 0.8 & 1.2 & 0.1 \\
\hline $2015 Q 4$ & -6.4 & -2.2 & 2.5 & 8.5 & -0.7 & -11.6 & -4.2 & -3.9 & 4.7 & 3.1 & 5.1 & -1.1 \\
\hline $2016 Q 1$ & 0.0 & 2.0 & 1.4 & -2.7 & -2.3 & 7.2 & 0.5 & -1.0 & 0.6 & -4.2 & 0.3 & -0.4 \\
\hline 2016Q2 & -0.5 & 2.4 & -0.2 & -4.7 & 0.1 & 2.5 & 2.0 & -1.5 & 0.8 & -4.5 & 0.6 & -0.1 \\
\hline 201603 & -0.1 & 2.7 & 0.5 & -4.0 & 1.0 & 0.0 & -0.3 & -2.9 & 0.9 & -2.7 & -2.8 & -0.1 \\
\hline $2016 Q 4$ & -2.2 & 3.2 & 1.4 & -3.7 & 0.4 & -3.0 & 1.2 & -2.9 & 0.0 & -2.1 & -1.3 & -0.1 \\
\hline 201701 & 1.9 & 2.8 & 2.1 & 2.4 & -0.5 & -2.2 & -0.2 & -0.1 & -1.1 & 3.0 & 0.5 & 1.0 \\
\hline $2017 Q 2$ & 4.8 & 3.4 & 2.7 & 3.3 & -0.4 & 1.0 & -0.6 & 0.3 & -2.6 & -2.2 & -0.7 & 0.6 \\
\hline $2017 Q 3$ & 9.1 & 3.2 & 1.4 & 0.2 & -0.8 & 1.4 & 1.5 & -5.4 & -3.4 & -1.3 & 3.4 & 0.3 \\
\hline $2017 Q 4$ & 3.4 & 2.0 & -0.4 & -5.6 & 0.9 & 1.5 & -1.1 & -0.6 & -2.2 & -0.1 & 1.4 & 0.4 \\
\hline $2018 Q 1$ & -0.8 & -0.4 & -3.5 & 5.8 & 1.0 & -0.2 & -1.5 & 1.4 & 1.4 & 1.3 & -0.4 & 0.6 \\
\hline $2018 Q 2$ & -0.4 & -0.9 & -2.9 & -0.8 & 0.4 & 3.9 & -1.4 & 2.6 & 2.4 & -0.7 & -0.7 & 0.3 \\
\hline $2018 Q 3$ & -0.1 & -1.2 & 1.0 & -1.4 & 0.7 & 4.3 & 0.0 & 2.9 & 2.2 & -0.4 & 1.9 & 0.5 \\
\hline $2018 Q 4$ & -1.0 & -2.3 & -3.9 & -2.3 & 2.3 & 6.0 & 2.7 & 3.4 & 1.7 & 0.1 & 0.3 & 0.9 \\
\hline $2019 Q 1$ & -3.4 & -1.5 & 9.0 & 2.2 & 0.6 & -3.6 & 0.5 & -1.0 & -0.9 & 0.9 & -2.5 & -0.6 \\
\hline $2019 Q 2$ & 0.5 & -2.3 & 5.2 & 4.2 & -0.2 & -0.2 & 1.3 & 2.3 & 2.3 & 2.5 & 2.8 & 0.5 \\
\hline $2019 Q 3$ & 3.2 & -0.8 & -3.4 & 1.8 & -0.6 & 0.2 & 2.3 & 3.8 & -0.4 & 1.0 & 1.1 & 0.7 \\
\hline $2019 Q 4$ & -0.4 & 0.9 & -3.2 & 1.0 & -2.8 & 0.6 & 3.1 & 0.2 & 0.1 & 1.9 & -2.0 & 0.1 \\
\hline
\end{tabular}

Source: Own calculations based on Eurostat, National Accounts (ESA 2010) data

*The represented sectors are as follows:
A Agriculture, forestry and fishing
B-E Industry (except construction)
C Manufacturing
F Construction

G-I Wholesale and retail trade, transport, accommodation and food service activities

$\mathrm{J}$ Information and communication

$\mathrm{K} \quad$ Financial and insurance activities

L Real estate activities

M_N Professional, scientific and technical activities; administrative and support service activities

O-Q Public administration, defence, education, human health and social work activities

R-U Arts, entertainment and recreation; other service activities; activities of household and extra-territorial organizations and bodies

GVA Total Gross Value Added in the economy 
Table 5. Individual sectoral contributions to total GVA output gap, in pps

\begin{tabular}{|c|c|c|c|c|c|c|c|c|c|c|c|c|}
\hline Year/ Sector & A & B-E & C & $\mathbf{F}$ & G-I & J & K & L & M_N & $0-Q$ & $R-U$ & GVA \\
\hline 2000Q1 & -0.2 & 0.6 & 0.8 & 0.1 & -0.1 & -0.2 & 0.1 & 0.1 & 0.1 & 1.1 & -0.1 & 1.4 \\
\hline $2000 Q 2$ & -0.6 & 1.3 & 1.0 & 0.0 & 0.3 & 0.0 & 0.1 & -0.2 & 0.6 & -0.9 & 0.2 & 1.0 \\
\hline 200003 & -1.1 & 0.6 & 0.2 & 0.0 & -0.4 & -0.1 & 0.1 & 1.0 & -1.5 & 0.8 & 0.0 & -0.7 \\
\hline $2000 Q 4$ & -0.6 & -0.1 & 0.0 & 0.0 & -0.1 & 0.2 & 0.1 & -1.0 & 0.2 & 0.2 & 0.3 & -0.8 \\
\hline 200101 & -0.4 & 0.3 & 0.1 & 0.1 & 0.4 & 0.1 & -0.4 & -0.1 & -0.1 & 0.1 & -0.1 & -0.1 \\
\hline 200102 & -0.5 & 0.2 & 0.1 & 0.1 & 0.4 & 0.1 & -0.1 & -0.7 & -0.7 & 0.0 & 0.0 & -1.2 \\
\hline 200103 & -0.6 & 0.1 & 0.1 & 0.1 & -0.9 & 0.1 & 0.0 & -1.3 & 0.3 & 0.2 & 0.0 & -1.9 \\
\hline $2001 Q 4$ & -0.3 & -0.3 & -0.2 & 0.1 & 0.3 & 0.1 & 0.0 & -1.3 & 1.4 & -1.7 & -0.2 & -1.9 \\
\hline $2002 Q 1$ & -0.1 & -0.8 & -0.5 & 0.0 & 0.1 & 0.4 & 0.1 & -0.5 & 0.9 & 0.3 & 0.3 & 0.7 \\
\hline 200202 & 0.2 & -0.4 & 0.0 & 0.1 & 0.0 & 0.2 & -0.3 & 1.1 & -0.9 & 1.0 & 0.0 & 1.0 \\
\hline $2002 Q 3$ & 0.5 & 0.1 & 0.0 & 0.0 & -0.2 & 0.3 & -0.2 & 0.9 & 0.4 & -0.2 & -0.2 & 1.4 \\
\hline $2002 Q 4$ & 0.0 & 0.0 & -0.4 & 0.0 & -0.6 & 0.1 & -0.1 & 1.4 & -0.6 & -0.4 & -0.2 & -0.4 \\
\hline 200301 & 0.1 & -0.5 & -0.4 & 0.0 & 0.1 & 0.2 & -0.1 & -0.1 & -0.4 & -0.1 & 0.3 & -0.7 \\
\hline $2003 Q 2$ & 0.2 & -0.4 & -0.4 & -0.2 & -0.8 & 0.2 & 0.1 & -0.6 & 0.1 & 0.3 & 0.2 & -0.9 \\
\hline $2003 Q 3$ & -0.2 & 0.4 & 0.1 & -0.3 & -0.8 & 0.1 & 0.0 & -0.1 & -0.1 & -0.3 & -0.1 & -1.4 \\
\hline $2003 Q 4$ & 0.2 & 1.0 & 1.3 & -0.3 & -0.8 & 0.0 & 0.0 & -0.1 & -0.3 & -0.2 & -0.4 & -0.9 \\
\hline $2004 Q 1$ & 0.2 & -0.7 & -0.9 & -0.2 & -0.5 & 0.2 & 0.1 & -0.2 & -0.8 & -0.5 & -0.3 & -2.5 \\
\hline 200402 & 0.3 & -0.6 & -0.7 & -0.2 & -0.1 & 0.2 & -0.5 & -0.9 & 0.2 & -0.6 & 0.0 & -2.1 \\
\hline 200403 & 0.8 & -0.4 & -0.7 & -0.3 & -0.2 & 0.1 & -0.3 & -1.0 & 0.0 & 0.2 & 0.2 & -0.8 \\
\hline $2004 Q 4$ & 1.0 & 0.1 & 0.0 & -0.5 & -1.4 & -0.2 & -0.2 & -0.4 & -0.2 & -0.7 & 0.0 & -2.6 \\
\hline $2005 Q 1$ & 0.1 & -0.2 & -0.3 & -0.1 & 0.2 & -0.3 & 0.3 & 0.0 & -0.5 & -0.2 & -0.2 & -1.1 \\
\hline $2005 Q 2$ & 0.0 & -1.0 & -0.8 & -0.4 & 0.4 & -0.3 & 0.3 & 0.0 & -0.7 & 0.5 & 0.0 & -1.0 \\
\hline 200503 & 0.3 & -1.6 & -1.2 & -0.3 & 0.6 & -0.3 & -0.2 & 0.1 & -0.4 & 0.4 & 0.0 & -1.3 \\
\hline $2005 Q 4$ & 0.0 & -0.1 & 0.1 & -0.6 & 0.1 & -0.4 & -0.5 & -0.2 & 0.0 & 0.2 & -0.1 & -1.5 \\
\hline $2006 Q 1$ & 0.0 & 0.2 & 0.0 & -0.3 & 0.3 & -0.5 & -0.4 & 0.0 & 0.6 & 0.3 & -0.3 & -0.1 \\
\hline $2006 Q 2$ & 0.1 & -0.3 & -0.3 & -0.1 & 0.8 & -0.6 & -0.4 & 0.3 & 0.3 & 0.1 & -0.4 & -0.2 \\
\hline $2006 Q 3$ & 0.7 & -0.4 & -0.4 & -0.2 & 1.2 & -0.5 & -0.5 & 0.4 & -0.2 & -0.3 & -0.1 & 0.1 \\
\hline $2006 Q 4$ & 0.6 & -0.2 & 0.1 & -0.2 & 0.6 & -0.4 & -0.4 & 0.7 & -0.3 & 0.7 & 0.2 & 1.1 \\
\hline $2007 Q 1$ & 0.2 & 1.4 & 0.9 & -0.1 & 0.4 & -0.8 & -0.5 & 0.5 & 0.4 & -0.1 & -0.1 & 1.4 \\
\hline $2007 Q 2$ & -0.2 & 1.0 & 1.2 & 0.0 & 1.5 & -0.8 & -0.1 & 0.5 & 1.3 & -0.6 & -0.3 & 2.5 \\
\hline $2007 Q 3$ & -3.9 & 1.3 & 1.4 & 0.2 & 1.5 & -0.7 & 0.6 & 0.3 & 0.4 & 0.0 & 0.0 & -0.3 \\
\hline $2007 Q 4$ & -1.3 & 2.0 & 1.7 & 0.3 & 0.9 & -0.8 & 0.4 & 0.7 & 0.8 & 0.5 & -0.2 & 3.3 \\
\hline $2008 Q 1$ & 0.2 & 2.8 & 2.1 & 0.3 & -0.3 & 0.8 & -0.8 & 0.5 & 0.7 & -0.4 & 0.4 & 4.2 \\
\hline 2008Q2 & 0.9 & 2.2 & 1.5 & 0.3 & 0.1 & 1.0 & -0.1 & -0.3 & -0.1 & -1.0 & 0.2 & 3.3 \\
\hline $2008 Q 3$ & 0.6 & 0.9 & 1.0 & 0.6 & 0.0 & 1.1 & -0.1 & 0.1 & 0.1 & -0.3 & 0.2 & 3.2 \\
\hline $2008 Q 4$ & 0.7 & 0.4 & 0.4 & 1.0 & -0.5 & 0.9 & 0.2 & -1.1 & -0.9 & 1.5 & 0.4 & 2.6 \\
\hline
\end{tabular}




\section{Articles}

\begin{tabular}{|c|c|c|c|c|c|c|c|c|c|c|c|c|}
\hline Year/ Sector & A & B-E & C & $\mathbf{F}$ & G-I & $\mathbf{J}$ & K & $\mathbf{L}$ & M_N & $0-Q$ & $R-U$ & GVA \\
\hline 200901 & 0.3 & -0.8 & -0.4 & 1.4 & 1.4 & 0.2 & 0.0 & 0.7 & -0.5 & -1.3 & 0.0 & 1.4 \\
\hline $2009 Q 2$ & 0.4 & -1.2 & -0.4 & 1.1 & -2.8 & 1.0 & 0.0 & 0.3 & 0.9 & 0.3 & 0.4 & 0.3 \\
\hline $2009 Q 3$ & 0.3 & 1.5 & 1.3 & 0.8 & -3.3 & 0.1 & -0.4 & -0.3 & 1.0 & 0.4 & 0.2 & 0.3 \\
\hline $2009 Q 4$ & 0.0 & -1.0 & -1.5 & 0.1 & -1.5 & 0.0 & -0.1 & -1.3 & -0.1 & 0.5 & 0.7 & -2.6 \\
\hline 201001 & -0.2 & -2.0 & -1.5 & -0.3 & 1.2 & -0.1 & 1.3 & 0.3 & -0.8 & 0.5 & -0.3 & -0.5 \\
\hline $2010 Q 2$ & -0.3 & -1.5 & -1.3 & 0.2 & -1.5 & 0.5 & 1.1 & 0.4 & 0.1 & 1.0 & -0.3 & -0.2 \\
\hline $2010 Q 3$ & -0.3 & -1.1 & -1.2 & -1.1 & 1.0 & -0.3 & 1.0 & 0.1 & 0.0 & 0.2 & -0.2 & -0.6 \\
\hline $2010 Q 4$ & -0.2 & -1.3 & -1.5 & 0.2 & 0.9 & -0.3 & 0.9 & -0.4 & 0.1 & -0.5 & 0.0 & -0.5 \\
\hline $2011 Q 1$ & 0.1 & -0.1 & 0.8 & -0.4 & 0.6 & 0.3 & -0.7 & -0.4 & 0.1 & 0.2 & 0.5 & 0.3 \\
\hline $2011 Q 2$ & 0.0 & 1.6 & 0.4 & -0.3 & 0.8 & 0.4 & 1.5 & 0.1 & -0.6 & 0.3 & 0.3 & 4.0 \\
\hline $2011 Q 3$ & 0.6 & -0.7 & -0.1 & -0.4 & 0.6 & 0.4 & 0.8 & 0.1 & -0.2 & 0.2 & -0.1 & 1.4 \\
\hline $2011 Q 4$ & 0.2 & -1.2 & -1.1 & 0.1 & -0.1 & 0.2 & 0.4 & 0.3 & 0.7 & -1.2 & -0.3 & -0.8 \\
\hline $2012 Q 1$ & -0.1 & 0.1 & 0.4 & -0.2 & -0.5 & -0.1 & 0.0 & 0.1 & -0.1 & 0.3 & 0.2 & -0.2 \\
\hline $2012 Q 2$ & -0.5 & 1.2 & 1.1 & -0.1 & -0.1 & 0.0 & -0.3 & 0.4 & -0.5 & 0.5 & 0.2 & 0.7 \\
\hline $2012 Q 3$ & -0.6 & -0.3 & 0.4 & -0.3 & -0.1 & 0.1 & 0.5 & 0.3 & -0.3 & 0.3 & 0.1 & -0.3 \\
\hline $2012 Q 4$ & -0.1 & -0.3 & 0.0 & -0.4 & 0.0 & 0.0 & 0.1 & 0.2 & 0.0 & 0.3 & -0.8 & -1.0 \\
\hline 201301 & 0.1 & -0.3 & -0.6 & 0.0 & 0.0 & -0.1 & -0.4 & -0.1 & -0.2 & -0.7 & -0.2 & -1.9 \\
\hline $2013 Q 2$ & 0.0 & -0.1 & -0.3 & 0.0 & -0.2 & -0.1 & -0.4 & -0.1 & -0.1 & -0.7 & -0.1 & -1.9 \\
\hline 201303 & -0.3 & -0.6 & -0.8 & -0.1 & 0.0 & 0.0 & -0.4 & -0.1 & -0.1 & -0.2 & 0.0 & -1.7 \\
\hline $2013 Q 4$ & -0.1 & -0.4 & -0.2 & -0.2 & 0.2 & -0.1 & -0.4 & -0.1 & 0.0 & -0.2 & -0.1 & -1.4 \\
\hline 201401 & 0.1 & -0.4 & -0.6 & -0.1 & -0.5 & -0.2 & -0.3 & -0.1 & -0.1 & -0.1 & -0.2 & -1.9 \\
\hline $2014 Q 2$ & 0.4 & -0.5 & -0.5 & -0.2 & -0.1 & -0.3 & -0.1 & -0.3 & -0.2 & 0.0 & -0.1 & -1.5 \\
\hline 201403 & 0.1 & -0.2 & -0.3 & -0.1 & -0.7 & -0.2 & -0.4 & -0.1 & -0.2 & -0.3 & 0.0 & -2.2 \\
\hline $2014 Q 4$ & 0.3 & 0.2 & 0.9 & 0.0 & -0.6 & -0.2 & -0.3 & 0.0 & -0.2 & 0.6 & 0.0 & -0.1 \\
\hline $2015 Q 1$ & 0.0 & -0.6 & -1.2 & 0.0 & 0.2 & -0.2 & -0.2 & -0.3 & 0.1 & 0.2 & 0.0 & -0.7 \\
\hline $2015 Q 2$ & 0.0 & -0.1 & -0.1 & 0.0 & 0.6 & -0.4 & -0.5 & -0.3 & 0.1 & 0.1 & 0.1 & -0.4 \\
\hline $2015 Q 3$ & -0.7 & 0.2 & 0.7 & 0.2 & 0.8 & -0.3 & -0.3 & -0.1 & 0.2 & 0.1 & 0.0 & 0.1 \\
\hline $2015 Q 4$ & -0.3 & -0.5 & 0.4 & 0.4 & -0.2 & -0.7 & -0.3 & -0.4 & 0.3 & 0.4 & 0.1 & -1.1 \\
\hline $2016 Q 1$ & 0.0 & 0.5 & 0.2 & -0.1 & -0.5 & 0.4 & 0.0 & -0.1 & 0.0 & -0.6 & 0.0 & -0.4 \\
\hline $2016 Q 2$ & 0.0 & 0.6 & 0.0 & -0.2 & 0.0 & 0.1 & 0.1 & -0.2 & 0.1 & -0.6 & 0.0 & -0.1 \\
\hline 2016Q3 & 0.0 & 0.6 & 0.1 & -0.2 & 0.2 & 0.0 & 0.0 & -0.3 & 0.1 & -0.4 & -0.1 & -0.1 \\
\hline $2016 Q 4$ & -0.1 & 0.8 & 0.2 & -0.1 & 0.1 & -0.2 & 0.1 & -0.3 & 0.0 & -0.3 & 0.0 & -0.1 \\
\hline $2017 Q 1$ & 0.1 & 0.7 & 0.3 & 0.1 & -0.1 & -0.1 & 0.0 & 0.0 & -0.1 & 0.4 & 0.0 & 1.0 \\
\hline $2017 Q 2$ & 0.2 & 0.8 & 0.4 & 0.1 & -0.1 & 0.1 & 0.0 & 0.0 & -0.2 & -0.3 & 0.0 & 0.6 \\
\hline $2017 Q 3$ & 0.4 & 0.7 & 0.2 & 0.0 & -0.2 & 0.1 & 0.1 & -0.6 & -0.2 & -0.2 & 0.1 & 0.3 \\
\hline $2017 Q 4$ & 0.2 & 0.5 & -0.1 & -0.2 & 0.2 & 0.1 & -0.1 & -0.1 & -0.1 & 0.0 & 0.0 & 0.4 \\
\hline 201801 & 0.0 & -0.1 & -0.6 & 0.2 & 0.2 & 0.0 & -0.1 & 0.2 & 0.1 & 0.2 & 0.0 & 0.6 \\
\hline
\end{tabular}




\begin{tabular}{|lrrrrrrrrrrrrr|}
\hline Year/ Sector & A & B-E & \multicolumn{1}{l}{ C } & \multicolumn{1}{l}{ F } & G-I & J & \multicolumn{1}{l}{ K } & L & M_N & O-Q & R-U & GVA \\
\hline $2018 Q 2$ & 0.0 & -0.2 & -0.5 & 0.0 & 0.1 & 0.2 & -0.1 & 0.3 & 0.2 & -0.1 & 0.0 & 0.3 \\
\hline 201803 & 0.0 & -0.3 & 0.2 & -0.1 & 0.1 & 0.3 & 0.0 & 0.3 & 0.1 & -0.1 & 0.0 & 0.5 \\
\hline $2018 Q 4$ & 0.0 & -0.5 & -0.6 & -0.1 & 0.5 & 0.4 & 0.2 & 0.4 & 0.1 & 0.0 & 0.0 & 0.9 \\
\hline 201901 & -0.2 & -0.3 & 1.5 & 0.1 & 0.1 & -0.2 & 0.0 & -0.1 & -0.1 & 0.1 & -0.1 & -0.6 \\
\hline 201902 & 0.0 & -0.5 & 0.9 & 0.2 & 0.0 & 0.0 & 0.1 & 0.3 & 0.1 & 0.3 & 0.1 & 0.5 \\
\hline 201903 & 0.2 & -0.2 & -0.6 & 0.1 & -0.1 & 0.0 & 0.2 & 0.4 & 0.0 & 0.1 & 0.0 & 0.7 \\
\hline 201904 & 0.0 & 0.2 & -0.5 & 0.0 & -0.6 & 0.0 & 0.2 & 0.0 & 0.0 & 0.3 & 0.0 & 0.1 \\
\hline
\end{tabular}

Source: Own calculations based on Eurostat, National Accounts (ESA 2010) data

*The represented sectors are as follows:
A Agriculture, forestry and fishing
B-E Industry (except construction)
C Manufacturing
F Construction

G-I Wholesale and retail trade, transport, accommodation and food service activities

$\mathrm{J}$ Information and communication

$\mathrm{K} \quad$ Financial and insurance activities

L Real estate activities

M_N Professional, scientific and technical activities; administrative and support service activities

O-Q Public administration, defence, education, human health and social work activities

R-U Arts, entertainment and recreation; other service activities; activities of household and extra-territorial organizations and bodies

GVA Total Gross Value Added in the economy 